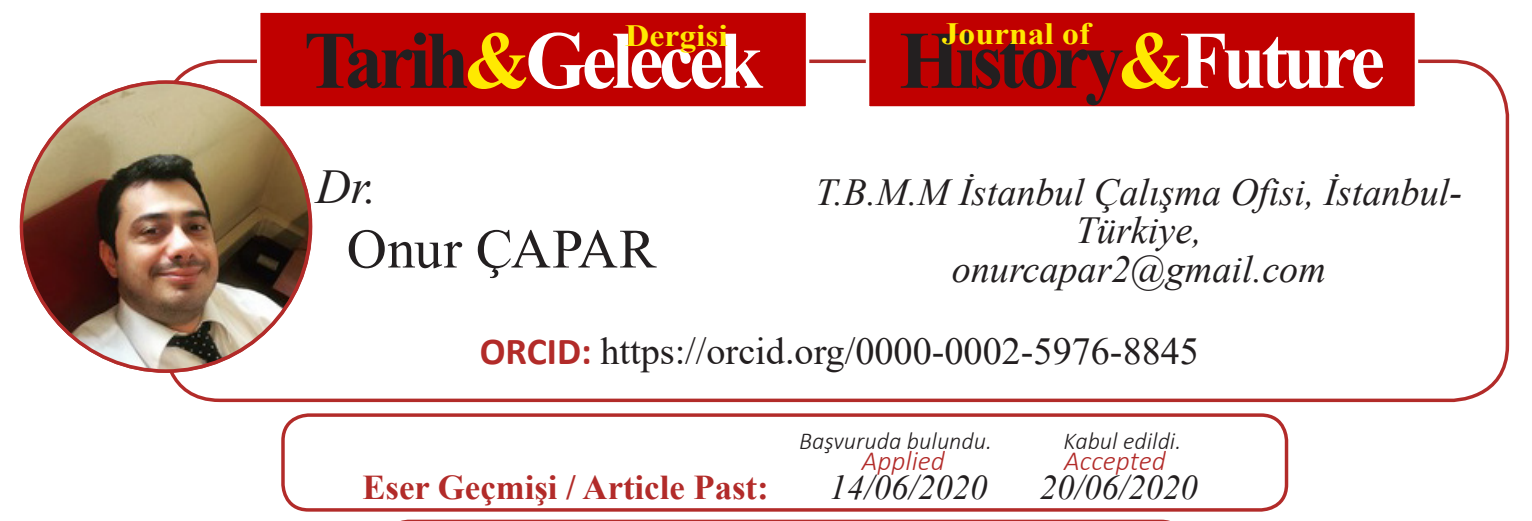

Araştırma Makalesi

DOI: http://dx.doi.org/10.21551/jhf.752712

Research Paper

Orjinal Makale / Orginal Paper

\title{
Bağımsızlıktan Sonra Kuzey Afrika Ülkelerinde Siyasi Süreç: Fas ve Libya Örneği
}

\author{
The Political Process in North African Countries After the \\ Independence: The Case of Morocco and Libya
}

$\ddot{O}_{z}$

Dünya'da son yıllarda artan toplumsal hareketler, özgürlük, eşitlik, adalet gibi konularda var olan sorunların giderilmesini amaçlamakta ve mevcut yönetimlerin toplumsal reformları hayata geçirmesi için zorlayıcı bir gündem oluşturmaktadır. 2011 yılından itibaren Kuzey Afrika ülkelerinde başlayan halk ayaklanmaları dünyada beklenmedik değişimlere sahne olmuş, bölgedeki ülkelerin birçoğunda iktidar değiş̧iklikleri yaşanmıştır. Bu ülkeler içerisinde demokratik süreci çatışmasız olarak halkın taleplerine göre şekillendiren ülkeler olduğu gibi halen iç savaş halinde bulunan ve belli çıkar gruplarının çekişmesinin devam ettiği ülkeler bulunmaktadır. Bu amaçla toplumsal hareketlerin başladiğ ülkelerin siyasi ve kültürel tarihlerini incelemek, bu hareketlerin içeriklerini anlamamı açısından elzem olmuştur. Genel itibarlyla Kuzey Afrika ülkelerinin tarihlerini incelediğimizde bu ülkelerin yerleşik kabile ilişkilerine derinden bağlı ve manda yönetimleri altında siyasi yapılarını kurdukları görülmektedir. Bölgede petrol gibi doğal kaynakların varlı̆̆ına răgmen kurulan bu siyasi yapıların ilkelliği, bu ülkelerin siyasi ve ekonomik olarak çok fazla gelişim gösterememesine sebep olmuş ve şu anda var olan huzursuzlukların kaynağ olmuşlardır. Bu çalışmanın amacı Kuzey Afrika 'nın önemli iki ülkesi olan Fas ve Libya'da manda yönetimlerinden sonra siyaset kurumlarını incelemek ve bu ülkelerde var olan iktidar ve muhalif çevreler arasındaki mücadelenin tarihsel gelişimine göz atmaktır.

Anahtar Kelimeler: Kuzey Afrika, Libya, Fas, Demokrasi, Siyasi Tarih, Siyasi Aktörler

ATIF: ÇAPAR Onur, "Bağımsızlıktan Sonra Kuzey Afrika Ülkelerinde Siyasi Süreç: Fas ve Libya Örneği”, Tarih ve Gelecek Dergisi, 6/2 (Haziran 2020), s. (685-708)

CITE: ÇAPAR Onur, "The Political Process in North African Countries After the Independence: The Case of Morocco and Libya", Journal of History and Future, 6/2 (June 2020), pp. (685-708) 


\section{Abstract}

The increasing social movements in the world in recent years aim to eliminate the problems that exist in issues such as freedom, equality and justice and create a compelling agenda for the current administrations to implement social reforms. The popular uprisings that started in North African countries since 2011 witnessed unexpected changes in the world, and power changes in many of the countries in the region. Among these countries, there are countries that shape the democratic process without conflict, as well as the demands of the people, as well as the countries that are still in civil war and where certain groups of interests continue. For this purpose, it is essential to examine the political and cultural histories of the countries where social movements started, in order to understand the contents of these movements. When we examine the history of the North African countries in general, it is seen that these countries are deeply connected to the established tribal relations and established their political structures under the mandate administrations. Despite the existence of natural resources such as oil in the region, the primitiveness of these political structures caused these countries not to develop much politically and economically and they were the source of the current unrest. The aim of this study is to examine the political institutions after the mandate administrations in Morocco and Libya, two important countries of North Africa, and to look at the historical development of the struggle between the ruling and opposition circles in these countries.

Keywords: North Africa, Libya, Morocco, Democracy, Political History, Political Actors.

\section{Giriş}

\section{Kuzey Afrika}

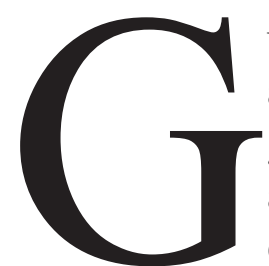

ünümüzde "Mağrip" olarak ta adlandırılan Afrika'nın kuzeyinde yer alan bu bölge içerisinde Fas, Tunus, Cezayir, Libya, Mısır, Sudan gibi devletleri barındırmaktadır. Geçmişte birçok devletin egemenliği altında kalmış bölge, zaman içerisinde çok çeşitli imparatorluklara ev sahibi yapmış, farklı etnik grupların yaşadığı bir bölge olmuştur. Bölgenin doğal sınırlarına baktığımızda; üç tarafı denizlerle çevrili olan bölge, Batıda Atlantik Okyanusu, Kuzeyde Akdeniz ve Doğuda Kızıldeniz arasında kalmaktadır. Aynı zamanda bölgenin güney sınırını oluşturan Sahra Çölü bölge için önemli bir rol oynamaktadır. Bölge denizlerle çevrili olmasından dolayı coğrafi olarak üç bölgeye ayrılmıştır. Bunlardan birincisi; Kuzeyde kıyı kesiminde bulunan, yeterince yağış alan, ekilebilir ve dikilebilir alanların bolca bulunduğu ve ticaretin gelişmiş olduğu bölgedir. $\mathrm{Bu}$ bölge yüzyıllar boyunca doğudan batıya doğru yoğun bir şekilde göç almıştır. Özellikle M.Ö. 2000 yılından itibaren Berberilere ev sahipliği yapmış olan bölge, M.S 7. yüzyılın ikinci yarısında Arapların göçüne sahne olmuştur. Bölge daha sonra deniz vasıtasıyla aldığ 1 göçler neticesinde sırasıyla M.Ö 1200'de Fenikelilere, M.Ö 146'da Romalılara, M.S. 5. ve 6. yüzyıllarda Vandalların istilalarına uğramıştır.

İkinci bölge ise batıdan Doğuya doğru uzanan özellikle yüksek dağların ve platoların 
yer aldığg bölgedir. Cezayir gibi ülkelerin bulunduğu bu bölge yerleşimi zor olduğu için nüfus yoğunluğu bakımından düşüktür. Güney kısmı oluşturan üçüncü bölge ise çölün egemen olduğu alanlardır. Özellikle Libya'nın orta kısımları ve batı Mısır'ı içine alan ve Sahra adı verilen bu bölge, düşük yoğunluklu bir bölge olmasının yanında bazı yerleşik toplulukları içinde barındırmaktadır ${ }^{1}$.

Kuzey Afrika'da kuzey-güney yönünde seyreden önemli akarsu havzaları bulunmaktadır. Özellikle Nil Vadisi denilen bu bölge; tarım açısından son derece verimli alanlara sahiptir. Yeterince yağış alan bu bölge de çok fazla tarım ürünü yetiştiği için farklı alanlarda ortaya çıkmış birçok ekonomik faaliyet bulunmaktadır. Bölgede kabile sistemi oldukça yaygındır. Özellikle Berberi kabilelerin yaygın olduğu bölgede kabileler birçok egemenlik sahasına girmiş ve çıkmış olmalarına rağmen kabile yaşamı değiş̧meden günümüze kadar devam etmiştir. Bölgede 9. yüzyılda başlayan Arap hâkimiyeti öncelikle bölge insanlarının Araplarla olan ticareti dolayısıyla artmış daha sonra Araplar tarafından kurulan ticari koloniler sayesinde bölge üzerinde hızla yaygınlaşmıştır².

$\mathrm{Bu}$ yaygınlaşmanın etkisiyle bölgede İslam'ın ağırlı̆ğ günden güne artmıştır. $\mathrm{Bu}$ dönemde Fâtımî Devleti'nin etkisi altında kalan Kuzey Afrika, aynı zamanda İspanya'da ki Emevilerin etkisiyle de Arapların bölge üzerindeki egemenliği artırdığı bir döneme girmiştir. 11. ve 12. yüzyıllarda bölgede yayılan Sünni İslam'ın etkisiyle, bölgede kurulmuş olan Berberi hanedanlığı Kuzey Afrika'nın büyük bir bölümünü yönetmiştir. Berberi kabileleri Sanhaja ve Lamtuna tarafindan kurulmuş olan bu hanedanlık, bugünkü Cezayir, Libya, Fas, Portekiz, İspanya'nın güneyi ve batı Tunus'u egemenliği altına almıştır. Hanedanlık üç bölgede yaygınlık kazanmıştır. İlk olarak batı Sahra'da Abu Bakr tarafından kurulmuş olan hanedanlık, bu bölgede Lamtüna kabilesi ve Ganalılar arasında savaşların yaşanmasına sahne olmuştur. Daha sonra batı Mağribi ele geçiren hanedanlık burada bir müddet hüküm sürmüş ve yayılmış, daha sonra Valencia'nın fethinden sonra İspanya'da egemenliğini genişletmiştir ${ }^{3}$.

Bölge daha sonra Memluk İmparatorluğu'nun etkisi altında kalmış, Yavuz Sultan Selim'in bu devleti 1516 yılında Mercidabık savaşında yenmesinin ardından Memlukluların bölgedeki etkisi azalmıştır. Osmanlı Devleti’nin bölgedeki etkisi ise 16. yüzyıla rastlar. 1517 yılında Mısır'ın fethi ile başlayan süreçte Osmanlı Devleti 400 yıl boyunca bölgeye hâkim olmuştur. 1492 yılında İspanya'da Müslümanlığın etkilerini yitirmesi ve Akdeniz'de Osmanlı hakimiyetinin başlaması bölgede klasik Arap modelli yönetim sisteminin değişmesine sebebiyet vermiştir.

Halifelik sistemine dayanan bu modelde yönetim Türk, Memluk ve Moğol politik modellerinden etkilenmiştir. Bu yönetimler daha önceki kabile ordularına nazaran küçük bir bürokrasinin desteklediği köleli ve paralı askerlerden oluşan bir yönetimdir. Osmanlı'nın bölgeye yerleşmesinden sonra politik olarak sufizm de bölgeye hâkim olmaya başlamıştır. $\mathrm{Bu}$ yönetim şeklinde hem ulema hem de sufilerin oluşturmuş olduğu organizasyonlar

1 Magali Morsy, North Africa 1800-1900 A Survey From The Nile Valley To The Atlantic (London: Addison-Wesley Longman Ltd,1984), 6.

2 Larouı Abdallah, The History of the Maghrıb (New Jersey: Princeton, 1977), 107.

3 Abdallah,167. 
sayesinde padişahın cömertçe desteğini alan bölge, padişahın atadığı Dayı veya Beylerle yönetilmiştir4.

Uzun yıllar Osmanlı Devleti'nin hâkimiyetinde olan Kuzey Afrika, 19. yüzy1l başlarından itibaren Avrupalı devletlerin egemenlilerini kurdukları bölge olmuştur. $\mathrm{Bu}$ dönemde Osmanlı Devleti'nin içinde bulunduğu zor şartlar sebebiyle bölgede Fransa, İtalya, İngiltere gibi devletlerin işgalleri gerçekleşmiştir. İlk olarak 1798 yılında Mısır'1 işgal eden Fransa daha sonra 1830 yılında gerçekleştirdiği Cezayir işgali, bölgedeki Osmanlı hâkimiyetini sonlandırmaya başlamıştır. Nitekim Berlin Antlaşması'ndan çok kısa bir süre sora Tunus'un 1881 yılında Fransa tarafından işgal edilmesi Osmanlı Devleti'nin Akdeniz havzasında hâkim olduğu toprak parçalarını kaybedeceğini göstermiştir5.

19. yüzyıldan itibaren Avrupalı devletlerin etkisi altına giren Kuzey Afrika'daki devletler yönetim açısından birbirlerinden ayrı bir tutum sergilemişlerdir. Fransa'nın etkisi altında olan Cezayir, Tunus ve Fas'ta yönetim sisteminde ve diğer alanlarda baştanbaşa, uzun soluklu ve sert bir değişim yaşanırken, İtalya'nın etkisinde olan Libya'da Osmanlı zamanındaki Beyliksistemine kısmen de olsa devam edilmiştir. Fas için ise koloni öncesindeki gibi krallıkla yönetilmesi sağlanmıştır. Bu dönemde özellikle Avrupalı devletler tarafından bölge halklarına büyük baskılar yapılmış, dil, din, kültür alanında birçok asimilasyon politikası uygulanmıştır.

Kuzey Afrika ülkelerinde bağımsızlık isteği Birinci Dünya Savaşından sonra başlamıştır. Fakat savaş sonrası yapılan barış antlaşmaları sonucunda bağımsızlık çabaları sonuçsuz kalmıştır. Bu dönemde Mağrip ülkelerinde gelişen reformist İslam'ın etkisiyle, Mağrip Müslümanlarına ulusal temalarla seslenilmiş, bunun sonucunda başlayan bağımsızlık mücadeleleri sonucunda bağımsızlıklar kazanılmıştır. Bu mücadeleler içerisinde en acı verici olanı Cezayir ve Fransa arasında olmuştur. Fransa'nın Tunus ve Fas'tan çekilişi ise İkinci Dünya Savaşından sonra en zayıf olduğu dönemde daha yumuşak bir biçimde gerçekleşmiştir. Aynı zamanda İtalya'nın İkinci Dünya Savaşı sırasında yenilmesi de Libya'nın bağımsızlığını kazanmasında etkili olmuştur'. Bağımsızlıktan sonra devletler; kendi yönetimlerini kurmuşlar ve ulusal temaların bolca işlediği dikta yönetimleriyle yönetilmişlerdir.

\subsection{Fas Bağımsızlık Süreci}

Fas'ın bağımsızlığını nasıl kazandığını anlatmadan önce, Fas'ın tarihsel kökenine bakmak ve ülkedeki hanedanlığın köklerini incelemek faydalı olacaktır. Fas; Kuzeyde Akdeniz, güneyde Sahra Çölü, Batıda Atlantik Okyanusu ve Doğuda Cezayir'e sınırlara sahip olan bir ülkedir. Fas'taki ilk yerleşimciler Berberilerdir. Neolitik çağlarda kendi çekirdek aileleriyle yaşayan bu insanlar daha sonra bu ailelerin birleşmesiyle birkaç ailenin oluşturdukları kabile sistemini geliştirmişlerdir. Zamanla bu kabileler birkaç köyün birleşmesiyle büyümüş bu kabilelerinde kendi aralarında birleşmesiyle birleşik kabile

4 Zartman William, Mark Habeeb William, Policy and Society in Contemporary North Africa (San Francisco: Westview Press, 1 edition 1993), 7.

5 Erol Karcı, “Osmanlı Kaynaklarına Göre Fransa’nın Tunus’u İşgali”, (Ankara: Gazi Üniversitesi SBE Tarih Ana Bilim Dalı Yüksek Lisans Tezi, 2007), 7.

6 Koloni dönemindeki yönetim şekilleri hakkında daha fazla bilgi için bkz: Zartman, Habeeb, Policy and Society in Contemporary North Africa, 9-13. 
yapıları oluşmuşlardır. Berberi kabileler M.Ö. 5. yüzyıla kadar yabancılardan bağımsız bir şekilde bölgede yaşamlarına devam etmişlerdir. M.Ö. 475 ve 450 yılları arasında bölgeye ilk kez Kartacalılar tarafindan koloniler kurulmaya başlanmıştır. Kartacalı Amiral Hanno tarafindan kurulan bugünkü Melilla ve Tangier bölgedeki ilk koloni şehirleridir. Roma'nın Kartaca'yı fethetmesi ile Fas'ın kapıları Roma'ya açılmıştır. M.S. 42 yılında Suetonius Paulinus bugünkü Tangier, Ceuta, Rabat ve Tingis'i de içine alan Mauratia Tingitanay adlı şehri kurmuştur. Bu dönemde Roma etkisi Fas'a bazı kabile şeflerinin yardımıyla yayılmıştır. Bölgede Roma tarafından tamamen bir egemenlik sağlanamamışsa da Romalıların yaşam biçimleri Faslıları oldukça etkilemiştir. Bugün bu etkiyi Fas mimarisi ve dilinde görmemiz mümkündür. M.S. 155 Roma İmparatorluğu yıkılmış sonra da Roma'nın bölgedeki etkinliği bir müddet daha devam etmiştir. Vandallar, 5. yüzyılda bölgeye hiçbir direnişle karşılaşmadan yerleşmişler fakat bölgede çok uzun kalmadıkları için bölgenin yapısına bir etkileri olmamıştır. Vandallardan sonra Tangier ve Ceuta'yı işgal eden Bizanslılar bölgeye çok fazla nüfus edememişlerdir. İlerleyen dönemde bölgeye İslam'ın gelmesi sonucunda Berberi kabileler politik birliği ve kendi aralarında devamlılığ yakalamışlardır. Bölgeye İslam'ın gelmesi ise M.S. 683 yılında Okba Bin Nafi ve emrindeki Arap ordusunun Şam'dan başlayarak Atlantik kıyılarına kadar ulaşmasıyla başlamıştır. $\mathrm{Bu}$ aşamada Arapların yaşam tarzından etkilenen Berberiler, 28 yıl sonra Tarık Bin Ziyad komutasındaki İslam ordusunda görev aldılar ve İspanya'nın fethine yardımcı oldular. 50 yıllık bir süre içerisinde de Berberilerin çoğu İslamiyet'i tanıdılar ve Arapların kültürlerini benimsediler. Fas ilk kez devlet olarak ortaya çıkması 788 yılında Şerif Maulay İdris zamanında olmuştur. Maulay İdris halife Harun Reşit zamanında Bağdat'tan Fas'a göç etmiştir. Hz. Muhammet'in amcasının soyundan gelmesinden dolayı diğer aile mensupları ile arasında birçok mücadele geçmiştir. Voulibis'e yerleşen Maulay İdris burada yerleştiği Müslüman kabileyi soyu, aklı, zekâsı, dindarlığı ile etkilemiş ve kabilenin başına geçmiştir. Bölgedeki diğer kabileleri de hızlıca birleștirerek bir kabile birliği oluşturmuş ve bölgenin diğer yerlerini fethetmeye başlamıştır. Maulay İdris sınırlarını doğuda bugünkü Cezayir topraklarında bulunan Tlemcen'e, güneyde ise Marrakesh'e kadar uzatmıştır. Fakat başarısı Halife Harun Reşid'e kadar gelmiş Halife kendisine bir suikastçı göndererek, kendisini 791 yılında öldürtmüştür?

Maulay İdris öldükten sonra İdrisi hanedanllğı bir berberi cariye olan karıs1 Kensa'dan doğan oğluyla devam etmiştir. Zeki ve yetenekli bir idareci olan 2. Maulay İdris, babasının 789 yılında kurmuş olduğu Fez şehrine taşınmış yönetimini ve etki alanını sağlamlaştırmıştır. Onun zamanında mahzen dediğimiz Kral'a yakın olan aristokrat çevre ilk olarak oluşturulmuştur. Daha sonra 2. Maulay İdris 829 yılında ölmüş ülke çocukları arasında bölüştürülmüştür. Tarihte Magrib üzerinde kurulmus olan en önemli İslâm devleti Murâbitlar Devleti'dir. 1056'da kurulan Murâbitlar zamanla bütün Kuzey Afrika'y1 ve Endülüs'ü içine alan 6.000.000 kilometrekarelik geniş bir bölge üzerinde hâkimiyet kurmuş ve buralardaki dağınıklığa son vererek bir birlik ve merkezi otorite oluşturmuşlardır.

Murâbıtlar'ın merkezi bugün Fas sınırları içinde kalan Merakes'ti. İslâm'ın kuzeybatı ve batı Afrika ülkelerine yayılmasında bu devletin önemli etkinliği olmuştur. Murâbıtlar'ın ilk sultanları Ebu Bekr ibn-u Ömer Lamtuni'dir. Ondan sonra ünlü cihangir Yusuf İbn-u 
Tasfin bu devletin başına geçmiştir. Devletin sınırlarının genişlemesinde Kuzey Afrika Müslümanları arasında birliğin sağlanmasında Yusuf İbn-u Tasfin'in önemli rolü olmuştur. Murâbıtlar 1147 yılına kadar ayakta kalabildiler. Bu tarihten sonra Muvahhidlerin hâkimiyeti altına girdiler.

Muvahhidlerin hâkimiyeti de 1269'a kadar sürdü. Muvahhidlerin dağılmasından sonra ise bölgeye yine küçük devletler ve emirlikler hâkim oldu. Meriniler (1197- 1550), Vattasiler 1470 - 1550), Sa'di Serifleri (1509- 1660), Filali Serifleri (1640'tan itibaren) Muvahhidlerin dağılmasından sonra bölgede hâkimiyet sürmüş olan yönetimlerdir. Bunlardan Meriniler, Muvahhidler dağılmadan önce kurulmuştu ve Fas'ın az bir bölümü üzerinde hüküm sürüyorlardı. Merinilerle Muvahhidler arasında bir çekişme de olmuştur. Ancak Muvvahhidlerin son zamanlarına doğru ortaya çıkan iç kavgalar Merinilerin isine yaradı ve onların dağılmalarından sonra da topraklarının bir kısmını ele geçirdiler. Vattasilerin hüküm sürdükleri dönemde Portekizli ve İspanyalı sömürgeciler Fas topraklarına saldırılar düzenlediler. Bu saldırılar sonunda Portekizliler Fas'ın Atlas Okyanusu kıyılarını ele geçirdiler. Sa'di Şerifleri Portekizli işgalcilere karşı mücadele ettiler ve 1578'de gerçekleştirilen Vadiyyu'l-Mehazin Savaşı sonrasında işgal altındaki toprakları geri aldılar. Filali şerifleri yönetimi daha Sa'di şeriflerinin Fas'ın bir bölümü üzerindeki hâkimiyetleri devam ederken kurulmuştur. Filaliler'le Sadiler arasındaki mücadeleyi sonuçta Filaliler kazandılar ve 1660'ta Sa'dilerin hâkimiyetine tamamen son vererek bütün Fas topraklarını ele geçirdiler. Bugün Fas'ta yönetimi elinde tutan kraliyet ailesi bu Filali sülalesinden gelmektedir ${ }^{8}$.

1830'da Fransa'nın Cezayir'i işgal etmesinden sonra bölgede Fransız etkisi hissedilmeye başlanmıştır. Fransa, 1830'dan sonra Fas'1 işgal etmeye çalışmışsa da ozaman ki güç dengelerinden dolayı bu işgali gerçekleştirememiştir. 1873-94 arası tahta kalan Kral 1. Hasan bu dönemde bağımsızlığı sürdüren son Fas sultanıydı. Kendisi düzeni sağliyordu fakat hem Avrupalı güçlerle hem de rejim muhalifi kabilelerle mücadele etmek zorunda kalmıştı. Oğlu Abdülaziz tahta geçtiği yıllarda sadece 14 yaşındaydı ve Avrupalı iş adamlarıyla etrafındaki vurguncuların etkisi altında kaldı. Abdülaziz babasının gerçekleştirdiği reformlara bağlı kalmaya çalıştı fakat bu çaba kabile şefleri, dini liderler ve toprak ağaları tarafından engellendi. Babasının zamanında alınan İngiliz desteği bu kaotik durum sonucunda yitirildi.

Bu aşamadan sonra 1904 yılından itibaren Avrupalı devletler Afrika topraklarındaki sömürgeler için aralarında anlaşmaya başladılar. İngiltere, Mısır'da hak iddiasında bulunmamak şartıyla Fransa'nın Fas'a girmesine razı oldu. Aynı şekilde İtalyanlar, Fransızların Fas'taki haklarını Libya'daki bağımsızlık rolünden dolayı kabul ettiler. Fransızlar ve İspanyollar hâkimiyet alanları hakkında anlaştılar. Sadece Alman İmparatoru Kayser II. Wilhelm 1905 yılında Tangier'i ziyaret ederek Fas'a desteğini sundu. Bu destekten ötürü Sultan Abdülaziz Fas'ın bağımsız bir devlet olarak kalması ve hükümdarlığın devam etmesi adına uluslararası bir konferans talebinde bulundu. 1906 yılında 11 ülkenin katılımıyla Fas'ın durumunu görüşmek üzere İspanya'da bir konferans toplandı. Toplantı sonucunda Fas hanedanlığının varlığı garanti altına alınıyor aynı zamanda Fransa'nın ve 
İspanya'nın ülkenin kıyı kesimlerinde ki şehirlerde polis ve finans kontrolünün de garanti altına alınması sağlanıyordu. Bu aşamadan sonra bu anlaşmayı birçok yeni düzenlemeler takip etti.

4 Mart 1910 tarihinde Fransa ve Fas arasında yapılan anlaşmaya göre Fransa'nın politik kontrolünde olacak sınır bölgesi yeniden düzenlendi. Fakat bu yapılan anlaşma iki devlet arasında nüfuz bölgesi problemlerini çözmedi. Aksine yapılan anlaşma daha önce Fransa'nın nüfus bölgesindeki haklarının bir tasdikini sağlıyordu. Ayrıca yapılan bu anlaşma 1912 yılında Fransız manda yönetiminden önce yapılan uluslararası son anlaşma olacaktı. ${ }^{9}$ Fakat iki ülke arasında nüfuz tartışması son bulmadı ve Fransa'nın bölgede yayılma isteği aynı zamanda Kral Abdülaziz ile Fransızların arasındaki yönetim ve ekonomik yetki sorunlarıyla birleşince manda yönetim sürecine geçiş hızlandı.

Bu aşamadan sonra Fransa bölgeyi işgal gücünü kendinde bulmuştu. Son bir oyalama olarak Moulay Hafız kardeşi Abdülaziz'i tahtan indirip kendisini sultan ilan etti. Fakat kabilelerin Fez şehrini kuşatması üzerine Moulay Hafız Fransızlardan yardım istemek zorunda kaldı. Bunun sonucunda Fas'ın kuzey bölgelerine İspanyollar asker çıkardılar. Hiçbir alternatif kalmayınca Moulay Hafız 30 Mart 1912 yılında Fez anlaşmasını imzalayıp Fransız ve İspanyol mandasını kabul etti. Devletin yüzyıllardır süren Osmanlı egemenliği böylece sona $\operatorname{erdi}^{10}$. 28 Nisan 1912 tarihinde ki kararnameye göre Fas, Fransa Cumhuriyeti tarafından atanmış bir valiyle yönetilecekti. Marshall Louis Lyautey, Sultan'ın yanında ülkeyi yönetmesi için görevlendirildi. Aynı tarihte Fransa'nın Fez konsolosu M. Henry Gaillard, genel sekreter olarak atand $1^{11} .1912$ yılındaki Fas'ta var olan devlet sistemine göz atarsak; 1912 yılında Fas hükümeti sultanın geçici ve ruhani teokrasisi altında yönetiliyordu. Peygamberin temsilcisi olarak görünen Sultan hem imam (ruhani lider), hem de emirel müminin yani inananların hükümdarı statüsündeydi. Yasa yapma, yargılama ve karar yetkisi onun ellerindeydi. Gücü sadece peygamberin emirlerini uygulayan ulema tarafindan sorgulanabiliyordu. Aslında Sultan'ın etkisi bir nevi askeri gücü ve liderlik vasıflarıyla ölçülüyordu.

Mahzen denilen Sultan'ın yakın çevresini oluşturan kimseler sadık kabile liderlerinden ve üyelerinden seçiliyordu. Bunların görevi Sultan'a danışmanlık etmek ve kendi kabilelerini kontrol altında tutmaktı. Sultan'ın ordusu kendi askerlerinden, kabilelerden alınan kimselerden ve paralı askerlerden oluşuyordu. Aynı zamanda ordu yarı organize olmuş birliklerden ve standart malzemelerinden yoksun bir yapılanma içindeydi. Mahzen ise iki kısımlı bir örgütlenme içindeydi. Bunlar daha çok hukuki alanda ve devlet işlerinde örgütlenmişlerdi. Birinci örgütlenmede sultanı korumakla görevli olan ve kutlamaları ayarlayan onu koruyan kişiler bulunuyordu. İkinci örgütlenmede ise merkezi bakanlık ve bölgesel hükümetleri temsil ediyordu. Merkezi bakanlık vezirin başında bulunduğu bir kurumdu. Sultan'a ait kararları uygulamaktan ve devlete bağlı kurumların iyi çalışmasından sorumluydu. Aynı zamanda Vezir karar alma hakkına sahipti. Merkezi yöneten vezirin dışında, Dışişleri, Savaş, Finans ve Adalet işlerine bakan vezirlerde mevcuttu. Yönetim

9 Frank E. Trout, Morocco's Saharan frontiers (Geneva: Vol. 1, Librairie Droz, 1969), 88.

10 Marvine Howe, Morocco The İslamic Awakening and Other Challenges (London: Oxford University Press, 2005), 64.

11 Henri Cambon, Histoire Du Maroc (Paris: Librairie Hachette, 1952), 228. 
Fransa'nın eline geçtikten sonra mahzenin durumu yenilendi. Dışişlerinden sorumlu vezirin yetkileri Fransa'nın atadığı valiye devredildi. Yine savaştan sorumlu vezirin yetkileri Fransız ordusuna devredildi. Adalet işlerine bakan vezir, sahradaki mahkemeleri kontrol etme yetkisine sahipti. Fakat finanstan sorumlu vezirin yetkileri Genel Vali'ye devredilmişti. Limanların yönetiminden sorumlu yeni bir vezirlik kuruldu. Mahzendeki üyeler Fransız hükümetinin Sultan'a sunduğu listelerden seçiliyordu. Yani mahzendeki üyelerin kim olacaklarına Fransızlar karar veriyorlard $1^{12}$.

Fransız mandası kurulduğu sırada Fas'ın kralı Filali sülalesinden Sultan Abdülhafiz'di. Fransızlar 7 Ekim 1912 tarihinde onu krallıktan uzaklaştırarak yerine yine Filali sülalesinden Ebu'l-Mehasin Yusuf'u geçirdiler. Fransızlar bu dönemde yarattıkları ulusçuluk teorileriyle Berberi halkla Arap halkın ayrışması için uğraştılar. Berberi halka kimliklerini hatırlatıp Berberi kabilelerin dillerini kültürlerini yeniden keşfetmelerini istiyorlardı.

$\mathrm{Bu}$ arada Birinci Dünya Savaşı başladı. Savaş sırasında sömürge devletlerine sağlanan askeri ve ekonomik fedakârlıklardan dolayı ile Kuzey Afrika'da bağımsızlık isteği artmaya başladı. Fakat bu istek savaştan sonra yapılan barış görüşmeleri sonucunda sömürge faaliyetlerinin devam ettirilme kararı ve ekonomik liberalleşme ile birlikte suya düştü. Bu dönemde Mısır'da ortaya çıkan Selefiye denilen İslami hareket sayesinde Mağrip Müslümanları arasında ulusal duygular güçlendi ${ }^{13}$.

1927 yılında Sultan Moulay Yusuf öldü. Fransızlar Yusuf'un henüz 18 yaşında olan oğlu seyit Muhammet bin Yusuf'u yani bilinen adıyla V. Muhammet'i tahta geçirdiler. Fransızlar V. Muhammed'i kendisinden daha büyük olan kardeşlerine tercih etmişlerdi. Çünkü onun daha yumuşak başlı olduğunu ve valiliğin verdiği talimatlara daha uygun hareket edeceğini düşünüyorlardı. Fakat Fas ulusalcıları kendisini ulusal bir sembol yapmakta kararlıydılar ve amaçlarına uygun olarak onu kazanmayı istiyorlardı. Kral bu duygulara elbette kayıtsız kalmadı. Fransızlar ile Kral arasındaki ilk anlaşmazlık 1934 yılında yaşandı. Kral, Fransız komitesinin 1930'da Berberilerle Araplar için iki farklı hukuk sistemi geliştiren yasayı kaldırmasını istedi. Aynı zamanda yönetim ve hukuk sisteminin birleştirilmesini istedi.

Bu durum ulusalcıların biraz daha cesaretlenmelerini sağladı. Ve 1934 yılında Manda yönetimine karşı örgütlü ilk kuruluş olan Fas Hareket Komitesi'ni kuran ulusalcılar, 1936 yılında ilk ulusal kongrelerini gerçekleştirdiler. Ve bu kongrede Watani partisini kurdular. Al Fassı partinin ilk genel başkanı oldu. Daha sonra ulusal hareket İspanya'nın kontrolünde olan bölgelere de yayıldı. Bu aşamada bağımsızlık için yeni partiler kurulmaya başlandı. Al Fass i ile diyalog halinde bulunan Abd El-Khalek Torres Teutan'da Ulusal Reform Partisi'ni kurdu. Mekki el Naciri daha sonra Torres'ten ayrılarak Fas Birlik Partisi'ni kurdu. İkinci Dünya Savaşı başlamasıyla ise Fas başlangıçta durağandı. 1940 yılında Fransa Almanya tarafından düşürülünce Fransız Fas'1 Vichy hükümetine bağlılığını bildirdi. Öte yandan Fas halkı Fransız ordusuna katılma konusunda pek istekli değildi. Sultan, Fransa'nın düşmesinden sonra ittifak güçlerinin desteğini arkasında hissederek Vichy hükümetine soğuk davrandı. Ve Fas'ta yaşayan Yahudilerin Faslılardan ayrı tutulmasını benimseyen

12 Cohen, Hahn, 31-36.

13 Zartman, Habeeb, 13. 
yasayı eleştirdi. Ayrıca Kral Muhammed 1943'te ABD başkanı Franklin D. Roosevelt'le özel bir görüşme yaptı. Roosevelt görüşmede Muhammed'in bağımsızlık yönündeki çabalarını desteklediğini söyledi.

Aralık 1943'de Watani Partisi ve yeni ulusalcıların birleşmesiyle İstiklal Partisi kuruldu. Bin Barka'nın liderliğindeki parti Ocak 1944'de Sultan'a niyetlerini ilettiler ve bir manifesto yayınlayarak bağımsızlık, birlik, Fas'ın bölgesel bütünlüğü ve Fas toplum sınıfının tüm haklarını elinde bulunduran demokratik bir düzen kurulmasını belirten ifadeleri bu manifestoda belirttiler ${ }^{14}$. Bu gibi faaliyetlerin sonucunda İstiklal Partisi mensupları ve ulusalcılara karşı tutuklanma dalgaları başladı. Bu baskı karşısında Kral V. Muhammet'in bağımsızlığı kazanmadaki kararlılığı daha fazla arttı. Bir süre sonra Sultan, Fransız Genel Valisi'nin yayımladığı kararnameleri imzalamayı reddetmeye başladı. Böylece kararnamelerin yasal açıdan bağlayıcı olmalarını engelleyerek sömürge yönetimine karşı etkili bir direniş yolu buldu.

$\mathrm{Bu}$ durum nedeniyle Kral Muhammet, Ağustos 1953 senesinde Fransızlar tarafindan önce Korsika'ya ardından da Madagaskar'a sürüldü. Yerine Fransızların kuklası olduğu tabir edilen kuzeni Moulay ben Arafa geçirilmişti. Ama yokluğunda bağımsızlık yanlılarının şiddet eylemleri bütün ülkeyi sardı ve birçok olay meydana geldi. Faslı Yahudilerin okulları ve iş yerleri ateşe verildi. Fransız ordusuna karşı gerilla savaşı yapıldı. Cezayir'deki ayaklanma nedeniyle güç durumda olan Fransız hükümeti Kasım 1955'te Kral Muhammed'in ülkesine dönmesine izin verdi. Aynı zamanda ulusalcıların serbest bırakılmasına da razı oldu ${ }^{15}$.

1955 yılından sonra şiddet olayları artarak devam etti. Mağrip özgürlük ordusu adındaki ordunun saldırıları her tarafta görülmeye başlandı. Gerilla taktiği kullanan savaş̧̧ılar Fransızlara çok zor durumlar yaşattılar. Önlenemeyen olaylar karşısında V. Muhammed Fransa'ya götürüldü, Fransız Dışişleri Bakanı Pinay ile bir dizi görüşmeler yapıldı. Görüşmeler neticesinde Fas'ın bağımsızlığı 2 Mart 1956 yılında tanındı. Fas'ın bağımsızlığı geleneksel yöneticilerin liderliği ile kazanıldı. İstiklal Parti'si ve onun öncüsü Ulusal Parti'si Fas'ın orta, alt ve çalışan sınıflarının politik bilinçlerini artırmasına yardım ettiler ${ }^{16}$. Aynı zamanda İstiklal Parti'si 1912 yılından beri ülkede var olan politik durumun değişmesini sağladı ve kendi döneminde geliştirdiği politikalarında devamlılığını sağladı.

\subsection{Bağımsızlıktan Sonra Fas’ta Siyaset Kurumu İşleyişi ve Muhalefetin Durumu}

Fas bağımsızlığını kazandıktan sonra siyaset kurumunun işleyişinde çok fazla bir değişiklik olmamıştır. Sömürgelerden kurtulan yönetim var olan siyasal otoritelerinde etkisiyle laik, ilerici, modern bir devlet düzeni yaratma vaadinde bulunmuş fakat ulusal temaların bolca işlendiği bu siyaset kurumu Kral'ın bütün yetkileri elinde tuttuğu ve mahzen denilen kralın etrafındaki küçük aristokrat grubun egemenliğini sürdürdüğü monarşik devlet yönetimini devam ettirmiştir. Kralın hiçbir şekilde sorgulanamadığı kendisinden başka siyasi ve dini yapının kabul görmediği bir sistem manda döneminden sonra da devam ettirilmiştir. Bu yönetim sistemi sonucunda halkın var olan talepleri görmezden gelinmiş muhalif hareketler bastırılmaya çalışılmıştır.

14 Cohen, Hahn, 43-46.

151953 ve 55 yılları arasında Fas’taki bağımsızlık mücadelesi için ayrıca bkz, Cohen, Hahn, 55-61.

16 Jamil Abun-Nasr, A History Of The Maghrib (Cambridge: Cambridge University Press, 1975 ), s. 377. 
Fas bağımsızlığını 2 Mart 1956 yılında kazandıktan sonra Kral bütün yetkileri eline aldı. En yakın arkadaşı M'barek Bekka'yı başbakan olarak atadı. Yine İçişleri ve Savunma Bakanlığı gibi görevlere kendi adamlarını yerleştirdi. Ulusal polis gücünü kendi kontrolü altına aldı. Ve oğlu Prens Hasan'1 kraliyet ordusunun başına getirdi. Bunun yanında ulusal hareketin geçmişteki keyfi yönetimin yerine modern, batı düşüncesinden etkilendiğini söylemek daha doğru olacaktır. İlk hükümet farklı politik güçlere bölünmüştü. İstiklal Partisi bağımsızlıkta baskın rolü üstlendiği için daha fazla sorumluluk arıyordu. Bunun yanında ulusu birleştirmek için Kral Muhammed küçük demokrat partilerin ve bağımsızların temsilcileriyle görüştü. Bu demokratik ortamın gelişmesi için ilk adım olarak Kasım 1956'da Ulusal Danışma Birliği'ni kurdu. Bu deneysel meclis bütçe, sosyal ve ekonomik problemler ve yabancı politikaların tartışıldığı bir kurumdu. Meclisin 76 üyesi Kral tarafından atanıyor ve siyasi partileri, bağımsızları, işçi örgütlerini, tarımsal kooperatifleri, profesyonel grupları ve din adamlarını temsil ediyordu. İstiklal Partisi'nin ve işçi federasyonunun ağırlıklı olduğu mecliste, partinin lideri Bin Barka başkan olarak seçildi. Başkan seçilmesinden sonra reformlar ve halk sorunları için mücadele etmeye başladı.

Sosyalist görüşlü olan Bin Barka bu aşamadan sonra liderlik özelliklerini göstermeye başladı. Onun önemli başarılarından birisi Kral Muhammed'in 1957 yılı yazında açılısını yaptığı kara yollarını birleştirme projesiydi. 10 bin gönüllü işçi ile birlikte önceki Fransız ve İspanyol bölgelerini birbirine bağlayan 40 millik bir yolu iki ay içerisinde tamamlamıştı. Aynı zamanda parti teşkilatının çalışmalarıyla toplu okuma yazma kampanyaları düzenledi. Daha birçok faaliyetlerde bulunan Bin Barka, Kral Muhammed'in gözünde reformcu ve organizasyoncu olarak görülüyordu. Fakat aynı durum Prens Hasan için geçerli değildi. Prens Hasan Bin Barkayı tehlikeli bir rakip olarak görüyordu. Bağımsızlıktan sonra Bin Barka ve diğer İstiklal Parti'si liderleri yeni bağımsız olan ülkelerdeki tek parti rejimlerinin yerine daha heterojen bir yönetim istiyorlardı. Ülke sömürge döneminden kalma birçok ekonomik ve sosyal problemlere sahipti. Fakat ülke hala politikacıların lüks harcamalarından mustaripti. Kral Muhammed politik güçlerin dengeli olmasını ve en güvendiği arkadaşı Bin Barka'yı başbakan olarak tutmaya devam etti. Fakat oğlu Prens Hasan'a daha fazla güç verilmesini ve ülke siyasetinde daha fazla rol verilmesini de sağladı.

Reformcu bir Kral olarak görünmek isteyen Muhammed bütün politik partilerin parlamentoda temsil edilmesini istiyordu. Fakat buna karşın oğlu Prens Hasan ise İstiklal Partisi'ni egemenliği altına almaya çalışıyordu. İstiklal Partisi'nin etkisini azaltmak için Prens arkadaşı Ahmet Reda Guedira'ya Liberal Özgürlük Partisi’ni kurdurdu. Politik etkisi olmamasına rağmen, bu hareket saray tarafından oldukça destek buluyordu. Bunlar gibi başka partilerin kurulması sonucunda İstiklal Partisi bölündü. 1959 yılında Bin Barka İstiklal Partisinden ayrıldı ve Sosyalist Birlik ve Popüler Güçler Partisi'ne katıldı. Bin Barka'ya yapılan baskılar bununla da kalmadı. Şubat 1960 'da Prens Hasan'a suikast iddiasıyla Bin Barka'nın en yakın adamları tutuklandılar. 23 Mayıs 1960'da ise Kral Muhammed mevcut hükümeti fesih edip oğlu Prens Hasan'dan yeni kabineyi kurmasını istedi. Prens Hasan'ın kurduğu kabine kendisine sadık olan kişilerden ve Bin Barka'nın saf dışı bıraktığı İstiklal Partisi üyelerinden oluşuyordu ${ }^{17}$. 
Kral Muhammed yönetimin ilk yıllarında kurmuş olduğu demokratik meclis zamanla oğlu Prens Hasan'ın kontrolüne geçti. Hasan kendisine sadık saray çevresinden kişileri ve daha liberal eğilimlileri yönetime getirdi. Bin Barka gibi hanedanlığa düşman olarak gördüğü kimseleri yönetimden uzaklaştırmaya çalıştı. Kral Muhammed 26 Şubat 1961'de beklenmedik bir şekilde öldü. Ölümünden sonra başa geçen oğlu Kral Hasan demokratik görünmeye çalıştı ve 1962 anayasasının yapılmasını emretti. Anayasa'da seçilmişlerden oluşan parlamento, çoklu parti sistemi, demokratik özgürlük gibi söylemler mevcuttu. Fakat gerçek güç Kral'ın elinde toplanıyordu. Anayasa yüzde 95 evet oyuyla kabul edildi. Bunun sonucunda içişleri, adalet bakanlıkları, polis ve ordu Kral'ın emrine verildi. Bu durum Hasan'ın tüm yetkiyi elinde tutacağını gösteriyordu. Bu aşamada 1963 yılında ilk seçimler yapıldı. Beklenildiği gibi hanedanın koalisyonu yani Liberal ve Popüler Hareket Partisi, İstiklal, Ulusal Birlik ve bağımsılardan oluşan bir meclis oluşturuldu. 7 ay sonra yerel seçimlerden önce Kral Hasan'a bir suikast söylentisi tertip edildi. Ulusal Birlik Partisi üyeleri ve Bin Barka hakkında tutuklama kararı çıkarıldı. Ve yüzlerce tutuklama gerçekleştirildi. Bu durum Kral Hasan'ın artık demokratik seçimlere pek önem vermediğini muhalifleri saf dışı etmenin yollarını aradığını gösterdi ${ }^{18}$.

Kral kendi isteklerine göre davranıyor. Kendisine muhalif olan herkese bask1 uyguluyordu. 1969 ve 71'deki darbe girişimleri Kral'dan ordunun da şikâyetçi olduğunu gösteriyordu. Bu iki başarısız darbe girişimi Kral'ı daha sert önlemler almaya yöneltti. 1970'lerde başlayan İslami muhalefet ise Kral'ın ölümüne kadar ülkedeki politik durum açısından başatbirgörev üstlenmiştir. 1970'denönceFas'ta ki İslami hareket Arap-Müslüman toplumunun sorunları ile meşguldü. Fakat İslami düşünürler İslam'ın birçok anayasal yapıya uygun modern bir sistem olmasına karşın var olan monarşik yönetimin modernleşmeci, batıl1, seküler bir yapıyı desteklemesini sorguluyorlardı. İslam'ın gelişmenin önünde bir engel olarak görülmesinin yanlış olduğunu savunuyorlardı. Aslında diğer Müslüman toplumlarda olduğu gibi Fas'taki İslami yapı 1960'larda genellikle sosyalist ulusalc1 Cemal Abdul Nasır'a karşı ortaya çıkan bir durumdu. Devlet İslamiyet'i bu durumda desteklemişti. Batıdan ve Nasırcılardan, Marksist Leninist tehditlerden korunabilmek amacıyla yüzünü Suudi Arabistan'a dönmüştü. Bunun sonucunda Vahabizim Fas'ta yayılmaya başladı. Fas'taki liderler Vahabilik'ten etkilenmiş olsalar da iki dost Arap monarşisinin Amerika ile soğuk savaş döneminden beri iş birliği içinde olduğu biliniyordu. Bu arada İran'da ortaya çıkan devrim, 20 yıldır politik baskılara maruz kalan Fas Müslümanlığı arasında büyük bir etki yarattı. İran'daki monarşiye ve Batı'nın kölesi olarak görünen askeri güçlere karşı alınan bu zafer Fas'taki Müslümanlar açısından umut ışı̆̆ı doğurmuştu19 .

Fas'ta organize olmuş ilk İslami grup 1969'da Abdülkerim Mutii tarafından kurulmuş olan İslami Gençlik Örgütüdür. Abdülkerim Mutii, Ben Berka'nın Ulusal Birlik ve Popüler Güçler Partisi'ne üye olmuş, daha sonra Bin Barka'yı komünist olmakla suçlayıp sağ görüşlü partilerde yer almaya başlamıştı. İslami Gençlik Derneği lise ve üniversitelerde öğrenciler ile hocalar arasında aktifti. Derneğin başlıca hedefleri arasında Arap eğitim sistemi, alkolün ve fuhuşun yasaklanması, İslami hukuk kuralların benimsenmesi vardı. İleri dönemdeki hedeflerinde ise ulusal kurumların tavsiye edilmesi ve iktidara gelmek vardı. Devrimci bir

18 Howe, 103-104.

19 Kral Hasan'a karşı darbe girişimleri için ayrıca bkz: Howe, 109-127. 
özellik taşıyan dernek kendi içinde beş hizip'e ayrılmıştı. Bu hiziplerden birisi Belçika'da basılıp Fas'ta el altından gizlice satılan El-Mücahid dergisinin yayınlamaya başlamıştır. El-Mücahid dergisinin ilk sayısının baş makalesi "Devrimci Müslüman gençlik, savaşa katılın!" başlığını taşıyordu. Bir diğer dergi El-Cemaat ise Marakeş’te, Fas'ın en tanınmış militan İslam ideoloğu Abdüsselam Yasin tarafından 1979'dan 1983'e kadar yayınlanmıştır. El Mücahid' ten biraz daha az radikal eğilimli olmasına rağmen yabancı tahakkümünün ve toplumsal adaletsizliğin mahkûm edilmesi El-Cemaat' in da her sayısında yer alan temel vurguları arasındadır. El Cemaat' in sayılarında Yasin, kapitalist batı ve komünist doğuyu Cahiliyyenin iki kampı olarak anarak Seyyid Kutup'u izlemektedir. Cahiliye kavramıyla, Seyyid Kutup gibi Yasin'de sadece İslam öncesi Arap toplumunun manevi cehaleti değil bütün gayri İslami toplumsal ve siyasal yapıları kastetmektedir ${ }^{20}$.

75 yaşındaki Şerif Yasin, Kral'ın dini otoritesine rakip olabilecek en büyük figürdü. Önce Sufizm etrafında şekillenen hareketini 1970'lerde bıraktı ve politikayla ilgilenmeye başladı. Laik ve ahlaksız bir yönetim anlayışı olarak gördüğü demokrasi içinde yer almayarak halifeliğin modern bir versiyonunu ya da şeriatın hâkim olduğu bir düzen kurmak istiyordu. 1974'de Yasin Kral II. Hasan'a ithafen 124 sayfalık bir mektup yazdı. Yasin bu mektupta saltanatın yozlaştığını içi boş olduğunu, demokrasi ve özgürlükten yoksun olduğunu, monarşinin değil İslam âlimlerinin seçeceği bir halifelik sistemine dönülmesi gerektiğini bildirdi.

Kral bu karşı çıkıştan sonra 1979 yılında olan İran İslam devriminden önce bir tehdit olarak görmediği İslamcıları daha fazla dikkate almaya başladı. Çünkü Kral hanedanlığın kendisine vermiş olduğu güçle beraber kendisini hem dini otoritenin hem de siyasi otoritenin mutlak hâkimi olarak görüyor, söz hakkının özellikle dini konularda kendisinde olduğunu düşünüyordu. Kral, Şeyh Yasin'i ve diğer İslam liderlerini bu aşamadan sonra göz hapsine aldı. Şeyh Yasin 1983 yılında çıkarmış olduğu Kral'ın sözleri ve davranışları arasındaki zıtlıkları irdeleyen bir makale yüzünden tutuklandı. 2 yıl hapse mahkûm oldu. Bu durumdan sonra Kral'ın İslami hareket üzerindeki baskıları daha da arttı. Dergilere ve yayınlara sansür uygulandı. İslami muhaliflere keyfi tutuklamalar yapıldı. Zorunlu tecritler uygulandı. Birçok muhalif işkenceden geçirildi. Tabi bu baskıcı durum muhalif çevrelerde daha büyük tepkilerin doğmasına neden oldu. Bu baskılar karşısında 1985 yılında Şerif Yasin muhtemelen şu anda Fas'ta ki başlıca İslami hareket olan Adalet ve İhsan Cemaati'ni kurdu ve yenilikçi yazılarını yayınlamaya devam etti. 1989 yılından itibaren ise Kral II. Hasan ölene dek süren bir ev hapsine mahkûm edildi. Şeyhin takipçileri ve müritleri tutuklandılar. Politik bir parti kurma istekleri reddedildi ${ }^{21}$.

Aynı zamanda Kral, 1980 yılından sonra ortaya çıkmış olan diğer İslami modernist çevreye yönelik böl ve yönet politikasını kullandı. Örneğin; Abdelillah Benkiran'ın kurmuş olduğu Jemaa Al İslamiya aktivistleri, aynı Şeyh Yasin'in maruz kaldığı baskıya maruz kaldılar. Dr. Kâtib'in yeni partisi PJD yani Adalet ve Kalkınma Partisi'nin seçimlere girmesine izin verildi. Ama kısaca modern İslami hareketin birleşmesine izin verilmiyordu.

20 Muhammed, Tozy, "Champ Et Contre Champ Politico-religieux au Maroc" (Marseille: Thcse pour le Doctorat d'etat en Science Politique, Universite de Droit, d'Economie et de Sciences d'Aix-marseille, 1984), 346-348. 
Baskıların ağırlaştığı dönemde muhalefet daha da artınca Kral biraz yumuşama kararı aldı. 1990'lı yıllarda bu yumuşamanın etkisiyle Fas'ın genel görüntüsü artık demokratikleşme ve reformların kök saldığı ve filizlerinin verdiği bir ülke durumuna gelmeye başladı. II. Hasan'ın 1997 yılında sosyal demokrat Abdürrahman Yusufi'yi başbakanlığa ataması ve 1999'da yerine modern olarak tanınan oğlu 6. Muhammed'in geçmesi şüphesiz bu resmi tamamlayan en önemli etken olmuştur. Ve gerçekten soğuk savaşın bitmesiyle Fas'ta önemli değişiklikler oldu. Artık insan hakları ayaklar altında çiğnenmiyordu, kadınların durumu günden güne iyileşmekteydi, geçmişteki adaletsizlikler hakkında açıkça konuşmak mümkün ve yolsuzlukların konuşulması artık yasak değildi.

Adalet ve İhsan Cemaati şeyhi, Abdüsselam Yasin 2006 yılının büyük değişim yılı olacağı kehanetinde bulunmuştu. Yolsuzluk, yoksulluk, ahlaksızlık, zengin ile yoksul arasındaki uçurum, bürokrasi ve varlıklı sınıfın batılı hayat tarzı bu şekilde devam edemezdi. Bunun yanında kendilerinin saray tarafından uysallaştırılmalarına izin vermeyen ve küçük bir iktidar karşılığında oyuna dâhil olmayı reddeden hareketler gerçek demokratik reformların yapılmasını istemişlerdir. Bu tarz muhalif hareketler bahsettiğimiz sert İslamcılardan ateşli insan hakları savunucularına kadar çok geniş bir yelpazede yer alıyorlar. Arada gazeteciler, ılımlı İslamcı partiler, radikal sol ve seküler partiler yer almaktadırlar. Bu hareketler demokrasinin gelişmesinin önündeki gerçek engel olan Kral'ın siyasi gücüne dikkat çektikleri için önemlidirler. Fakat var olan düzende halkın ve diğer siyasi partilerin demokratik olgulara biraz yabancı olması, okuryazarlığın düşük olması, yoksulluğun yaygın olması gibi durumlar demokratikleşme çabalarını istenilen düzeyde gelişmesine engel olmaktayd.

Eylül 2007'de her üç Faslı'dan ikisi seçimlere katılma zahmetinde bile bulunmadı. $\mathrm{Bu}$ durum şüphesiz demokratikleşme çabalarının önündeki en büyük engeldi. Seçimlerden sonra Adalet ve Kalkınma Partisi'nin önemli kazanımları oldu. Adalet ve Kalkınma Partisi İslami bir parti olmakla beraber, Kral'ın gücünü kabul ettiklerini ama bu gücü demokratik reformlarla sınırlandırabileceklerini düşünüyorlardı. 2005 ve 2006 yılında yapılan kamuoyu yoklamalarında oyların yarısını alabileceği söylenen parti, katılımın az olması sebebiyle oyların sadece \%11'ini alabildi. Bu da parlamentoda 46 sandalye demekti. Ve iktidardaki İstiklal Partisi'nden 6 eksikti. Bu durum ülkedeki İslami hareketin yükselişini ve Kral'ın var olan reformlarla etkisinin azaltılmak istendiğine bir işaretti.

Tahta çıktığı sırada fakirlerin kralı olarak adlandırılan Kral Muhammed radikalizmle mücadele için gelişim için ulusal inisiyatif programını ortaya koydu. 2009 yılında tüm gecekonduları ortadan kaldırılacak ve yoksulluk sınırı altında yaşayan Faslıların sayısı yarı yarıya indirilecekti. Kaldı ki Faslıların \%14'ü günde 2 dolardan daha az ile yaşamakta, orta sınıfa mensup olduğu söylenen $\% 30$ ise gerçekte yoksulluk sınırında yaşamaktadır. Nüfusun sadece \%16'sının sağlık sigortası vardır²2.

$\mathrm{Bu}$ gibi devlet destekli projeler ilerlemenin yolunu açmıştır. Ülke II. Hasan dönemindeki gibi işkence ve kayıpların doğal sayıldığı bir ülke olmaktan çıkmıştır. Tabi bu durum bazı istisnaları barındırmakla beraber ülke çevre ülkelere göre sivil toplumun

22 Joost Lagendijk, Jan Marinus Wiersma, Avrupa’nın Müslüman Komşuları (İstanbul: İletişim Yayınları, 2009), 114-126. 
yoğunluk kazandığı ve değişimin Arap Baharından önce başladığı bölgedeki tek ülkedir. Ülkede hala daha bir demokratikleşmeden söz edilemez fakat Arap Baharı sürecinde yapılan reformların etkisiyle var olan değişim süreci devam etmiştir.

\section{Libya Bağımsızlık Süreci}

Bölgenin bir diğer önemli ülkesi Libya ise Batı'da Tunus ve Cezayir, Güney'de Nijer, Çad ve Sudan ve Doğu'da Mısır olmak üzere altı Afrika ülkesiyle sınır komşusudur ve Afrika'nın en büyük ikinci ülkesidir. Geniş toprakları olmasına rağmen 5 milyondan az nüfusu ile seyrek nüfuslu bir ülkedir. Ülke topraklarının sadece \%10'u yerleşime uygundur. Ülke nüfusunun \%57'si sahil kesimindeki büyük kentlerde Tunus'la Misır arasındaki sahile paralel olarak uzanan 100 kilometre genişliğindeki bir alanda yaşar. Ülkenin iç kesimlerindeki birkaç vahada kurulan yerleşim merkezleriyle, dar sahil şeridi üzerinde kurulan yerleşim merkezleri arasında uçsuz bucaksız çöller bulunur ${ }^{23}$. Ülkedeki doğal sınırlar ülkeyi Berka, Trablus ve Fizan olmak üzere 3 bölgeye ayırmıştır. Ülkenin uygarlık tarihine kısaca bir göz atarsak Libya tarihi M.Ö. 1000 yılında Fenikeli denizcilerin Libya kıyılarına ulaşmasıyla başlamıştır. Fenikelilerin Trablus ve Berka kıyılarında koloniler kurdukları bilinmektedir ${ }^{24}$. Bu dönemlerde Berka Yunanlıların; Tripoli ise Kartaca ve Romalıların egemenliğinde kalmıştır. Daha sonra M.Ö 600 tarihinde Kartaca İmparatorluğu bu kolonileri ele geçirmiş ve ülkeye hâkim olmuştur. M.Ö. 264-218 y1lları arasında ise Kartacılarla Romalılar savaşmışlar bu savaşların sonucunda Kartaca Krallığ 1 yıkılmış ve bölge Romalıların eline geçmiştir. Roma dönemi başında ülke Roma Barışı sayesinde refah içinde yaşamış ticari ve kültürel açıdan ilerlemiştir ${ }^{25}$.

Kartacalılar bölgede kalıcı yerleşim merkezleri kurmuşlardır. Bölgede yaşayan Berberiler, Kartaca uygarlığından fazlaca etkilendiler ve onların dil, kültür, dini inançlarını benimsemişlerdir. Bölgenin Arap hâkimiyetine girmesi ise 642 yılıyla birlikte başlamıştır. Berka 'ya giren Arap kuvvetleri, Libya'nın batı ucunda yer alan Trablus'a gelinceye kadar hiçbir direnişle karşılaşmadılar. En güçlü direniş iç kesimlerdeki Berberilerden geldi. Berberi kabileleri 663 yılına kadar hâkimiyet altına alınamadılar. Berberilerin başkenti Germa, Ukba Bin Nafi tarafından ele geçirildi. Böylece Libya'nın kapıları sonuna kadar Araplara açılmış oldu ${ }^{26}$. Daha sonra kurulan Fâtımî halifeliğinin etkisiyle bölgeye Arap yarımadasından birçok göç gelmiştir. Özellikle Beni Hilal kabilesinden yaklaşık 200 bin ailenin Libya'ya yerleştiği tahmin edilmektedir. Beni Hilal kabilesi Fas'a ve Atlantik Okyanusu sahiline ulaşana kadar batıdaki yayılmaları sürdürürken, Beni Süleym kabilesi Libya'ya yerleşme kararı aldı. Yayılan bu kitlesel göç bölgenin zamanla Araplaşmasına sebep oldu.

Ülke bir müddet İspanyolların etkisine girdiyse de bu çok fazla uzun süreli olmamıştır. $\mathrm{Bu}$ dönemde Trablusgarp Limanı İspanyollar tarafindan ele geçirilmiştir. Osmanlı Devleti’nin ülkeyi ele geçirmesi ise 1551 yılında Kanuni Sultan Süleyman döneminde

23 Mansur Ömer El-Kihya, Libya’nın Kaddafisi (İstanbul: Kaknüs Yayınları, 2011), 34.

24 Celal Tevfik Karasapan, Libya, Trablusgarp, Bingazi ve Fizan (Ankara: Resimli Posta Matbaası Ltd. Şirketi, 1960), 48.

25 Majid, Khadduri, Modern Libya A Study in Political Development (Baltımore: The Johns Hopkins Press, 1963), 4.

26 Khadduri, 6-10. 
olmuştur. Trablusgarp'1 İspanyolların almak üzere görevlendirilen Kaptan-1 Derya Sinan Paşa ülkeyi Osmanlı topraklarına katmıştır. Öncelikle Cezayir ve Tunus'la beraber yönetilen ülke daha sonra ayrı bir eyalet olarak yönetilmiștir. Bu eyaletlerin tamamına Garp Ocakları denilmiştir. Libya'daki garp ocakları Osmanlı yönetimine en bağlı olanı olarak ortaya çıkmıştır ${ }^{27}$. Trablusgarp Eyaleti 1551-1864 yılları arasında yarı bağımsız olarak Dayılar tarafindan yönetilmiştir. 29 Temmuz 1711 tarihinde Araplar ile birlik olan Dayı yönetimi Karamanlı Hanedanı'na geçirmiştir. Karamanlı hanedanlığı ülkede 1835 yılına kadar devam etmiştir.

1864 yılında İstanbul'a bağlı normal bir hayat süren normal bir vilayet haline dönüştürülen Trablusgarp'ın yönetimi 1911 yılına kadar bu şekilde devam etmiştir. Bu dönemde Osmanlı Devleti merkezi yönetimi güçlendirmeye çalışmış, diğer taraftan da eyaletin iç bölgelerindeki denetimi altına almaya çalışmıştır ${ }^{28}$. Libya, Osmanlı yönetiminde iken birlik ortamı oluşturulmuş, bu sayede ülkede düzenli bir siyasi birlik ve ordu kurulabilmiştir. Ordunun kurulmasıyla birlikte ülkede meydana gelen İtalyan işgaline karşı direnişin temeli de atılmış olacaktır. İtalya, sömürgeci Batı toplumlarının içinde sömürge yarışına en geç katılanıdır. Sömürgecilik yarışına karar verince Kuzey Afrika'da işgal edebileceği tek yerin Libya olduğunu anlamış ve harekete geçmiştir. Bu bölgeyi kontrol altına alabilmek için 1911 yılından itibaren bölgeye asker çıkarmaya başladı. 1912 yılında imzalanan Uşi antlaşması birlikte ise ülke İtalyanların eline geçmiştir. Fakat Libyalılar ülkelerinin bir Hıristiyan devlet tarafından işgal edildiği gerekçesiyle 20 y1l kadar İtalyanlara direnmişlerdir. Bu aşamada İtalyanlar ancak 1932 yılında Libya'da dirlik ve düzeni kurabilmişlerdir ${ }^{29}$.

1923-32 y1lları arasında Ömer Muhtar önderliğindeki direnişçi gruplar İtalyan ordularına karşı başarılı mücadeleler vermiş, daha sonra Ömer Muhtar'ın 1932 yılında yakalanıp İtalya tarafından idam edilmesi sonucu ülkeye tamamen İtalya egemen olmuştur. Özellikle Muhammed bin Ali Es-Senusi tarafından kurulan Senusi tarikatının bölgede uygulamış olduğu direniş İtalyanlara birçok zarar vermiş ve ülkenin kontrolünü sağlamasını geciktirmiştir $^{30}$.Ülkede İtalyanların etkisi İkinci Dünya Savaşına kadar sürmüştür. Bu zamana kadar ülkede İtalyanların uygulamış olduğu şiddet, zulüm ve baskı sonucu binlerce Libyalı infaz edilmiş, tutuklanmış ve çeşitli işkencelere maruz kalmıştır. İkinci Dünya Savaşı'ndan sonra ise İtalyanların ülkeden çıkarılmasından sonra ülke Fransızlar ve İngilizlerin denetimi altına girmiştir. Bu aşamadan sonra İtalyanlarla mücadele sırasında Misır'a sürgüne gönderilen Senusi tarikatının lideri Şeyh İdris 1944 yılında ülkesine dönmüştür ${ }^{31}$.

Berka'da bir Senusi yönetiminin kurulmasını amaçlayan ve İdris'in en önemli destekçileri olan tutucu kabile reisleriyle, ülke topraklarının birleşmesinden yana olan genç kentli kesimler arasındaki anlaşmazlık 1949 yılında birleşmiş milletlerde çözüme kavuşturdu. Yayınları, 2006), 1-3.

28 Jack Wright, Libya: A Modern History (London: Croom Helm, 1981), 11.

29 Şıvgın, 141.

30 Senusi hareketi ile ayrıntılı bilgi için bkz: El-Kihya, 44-53.

31 Seyyid idris hakkında ayrıntılı bilgi için bkz: Khadduri, 22-27. 
Birleşmiş milletler Berka, Fizan ve Trablus'un geleceğinin üç bölgenin temsilcisinden oluşturulacak ulusal bir meclisle belirlenmesinin kararlaştırdı. Daha sonra Libya, Dünya konjonktüründeki gelişmeler sebebiyle 24 Aralık 1951 tarihinde bağımsızlığını kazanmış ve Birleşik Krallığın katkılarıyla ülkenin başına Kral olarak Senusi tarikatının lideri Şeyh İdris geçmiştir.

\subsection{Bağımsızlıktan Sonra Libya Siyaset Kurumu ve Muhalefetin Durumu}

Kral İdris tahta oturduktan sonra ülkede var olan birçok politik ve ekonomik problemle baş etmek durumundaydı. Ülkede siyasi bir birlik yoktu çünkü Libya etrafındaki ülkeler gibi kolektif bir bağımsızlık fikrinden yoksundu ve büyük ülkelerin desteği ile bağımsız olmuştu. Hala kendi içinde bölünmüş olan şehirlerden ve kabile sistemine dayalı bir federatif yönetimlerle yönetiliyordu. Kurulan ulusal mecliste her kabilenin kendisine ait kuralları ve yönetim şekli var olduğu için politik bir bütünlük sağlanamıyordu. İdris, politik bir hanedanlık kurmak, ülkede ulusal bir kimlik yaratmak ve farklı özellikteki kabilelerden bir devlet sistemi inşa etmekle istiyordu ${ }^{32}$.

Mısır'da sürgünde bulunduğu sırada Kral İdris, Bedevi bağlılı̆̆ının sürdüğü kabileler arasında bölünmemiş bağımsız bir Libya siyasetini benimsemişti. İtalyan işgali sırasında İngiltere İdris'i sadece dini bir örgütün başı olarak tanımlamaktan çok kendisini direnişin lideri olarak gördü ve kendisine asker toplaması için para yardımı yaptı. Bu arada propaganda yapması için de yardımda bulundu. Ayrıca İngilizler Senusilerin kontrolünde olan Sirenayka bölgesinin ve Trablus'un ayrı bir devlet olarak kurulmasını engellemeye yardımcı oldular. Bu arada Senusilerin kalesi konumunda bulunan Sirenayka da dahi farklı kabile örgütlenmeleri görülüyordu. İdris'in hükümdarlığ1 ve İngiltere'nin bölgeye kontrol amacı olarak yerleşmesini isteyen şehirler ve bölgeler bulunmaktaydı. Örneğin; Derne şehri doğuda entelektüellerin politik merkezi olarak görülüyordu. Ayrıca yeni devletin dini hatlarla şekillenmesine katkısı oldu. Mısır'daki Libya sürgünleri tarafından kurulan Ömer Muhtar Derneği ise İngiliz yönetimini istemiyordu. Trablus ile Bingazi ise birlik isteyen genç milliyetçilerin merkezi haline gelmişlerdi. İlerleyen zamanda İtalyan yönetiminde ayrı bir vilayet statüsüne sahip Trablus gibi birçok bölge dağılmak yerine Senusi idaresini kabul etti.

Ayrıca İdris ile İngiltere arasındaki ilişki Senusi krallığından öte simbiyoz bir ilişki çerçevesindeydi. İngiltere İdris'e krallığını kurması konusunda bazı ithal yöneticiler de dahil olmak üzere yardımcı oluyordu. Buna karşı1ık Kral ise Mısır'ı elinde bulunduran İngilizlere birtakım garantiler veriyordu. Sonuçta o dönemde batılı ülkeler tarafından monarşi yönetim sisteminin desteklenmesi, Ortadoğu milliyetçiliği ve pan arabizm adı etrafinda kitlelerin tepkilerini engellemek için iyi birer araç olarak kullanılıyordu. Bunun sonucunda egemen ülkenin ülkedeki kaynakları kullanmasına ve pazar yaratmasında bu monarşiler yardımcı oluyorlardı. Bağımsızlıktan sonra krallığın gücü iki temel sistemden gelmekteydi. Bunlar Arap monarşisinin kurduğu dini meşruiyet iddiası ve kralın öndelik ettiği dini emirliklerdi. Bunun yanında kabile klanlarının kendi içlerinde daha özerk bir yapıda oldukları fakat Senusi hanedanının etrafında onun siyasi otoritesine itaat etmeleri

32 Dirk Vandewalle, Libya Since İndependence Oil And State Building (London: Cornell University Press, 1998), 43-44. 
sağlanarak Senusi hiyerarşisi güçlendirilmişti ${ }^{33}$.

1943 yılında Kral İngilizler 'in izniyle Mısır'da gelerek Sirenaik’in bağımsızlığını ilan etti ve İngilizlerden ülkenin bütün yönetiminin kendisine verilmesini istedi. Daha sonra 1949 yılında Trablusgarp, Bingazi ve Fizan federal bir çatı altında Libya Devleti'nin kurulmasını sağladılar. Trablusgarp ve Fizan temsilcilerinden oluşan ilk Libya Milli Meclisi, 25 Kasım 1950'de toplanarak Libya Federal Devleti'nin kuruluşunu ve 3 Aralık 1950'de Şeyh İdris'in krallığını ilan etti. 7 Ekim 1951'de ise bu defa Bingazi de toplanan Libya Milli Meclisi federal meclisin anayasasını onayladi ${ }^{34}$.

7 Ekim 1951 anayasası federal anayasal bir monarşi kurmuştu. Federalizm her üç eyaletin de kendi içişlerini ayrı ayrı sürdürmesini sağlayan, dengeli bir sistem kurmuştu. Özerklik, geleneksel üst sınıfın yönetimdeki otoritesinin devamını sağlamıştı. Bu anayasayı oluşturanlar anayasal sistemden önce kurulan monarşiye ek olarak iki kısımlı bir parlamento ve birde anayasa mahkemesi kurdular. Bu üç kurum, hükümdarı diktatörlüğe özgü güçlerle donatmak amaciyla geleneksel düzeni korumuştu.

Libya anayasasına göre Kral her türlü sorumluluktan muaftı. Yasa çıkarabilir, yasaların uygulanma şeklini belirleyebilir, sıkıyönetim ilan edebilir, genel seçim tarihlerini ilan edebilir ve istediği zaman parlamentoyu toplayabilirdi. Kral aynı zamanda Başbakanı, Kabine üyelerini ve Bakanları kendisi göreve getirebilir veya görevden alabilirdi. Parlamento ise Senato ve Temsilciler Meclisi olmak üzere ikiye ayriliyordu. Senato, eyaletleri temsil eder ve 24 üyeden oluşurdu. Temsilciler meclisi ise seçilen milletvekillerinden oluşuyordu. Kral, meclisten ya da senatodan çıkan yasa tasarılarının kabul edilmesini ve reddedilmesini sağlayabiliyordu. Ülkede sivil, din ve anayasa mahkemesi olmak üzere 3 çeşit mahkeme bulunmaktayd1. Kral bu mahkemelere istediği gibi müdahale edebiliyor ve mahkemelerden çıkan kararları etkileyebiliyordu. Ülke, modern ve ileri kurumlara sahip olmasına rağmen siyasi sistemde önde gelen kabilelerden ve ailelerden seçilmiş olan üyeler etkindi. Başbakanlar eğitimine ve yeteneklerine bakılmaksızın sarayla ilişkilerinin yoğunluğuna göre seçilirlerdi. 1951 yılından sonra düzeni sağlamak amacıyla ülke ekonomik ve politik olarak büyük devletlerin yardımlarına bağlı duruma geldi. Ülke bağımsızlıktan sonraki ilk 10 yılda dış destekli yardım ve yabancı uzmanların sayesinde devlet sistemini oturtmaya başlamıştı. Özelikle 1959 yılında petrol kaynaklarının keşfedilmesi sayesinde Amerika Birleşik Devletleri ve İngiltere ülkedeki petrolün endüstrisinin gelişmesini sağlamışlardır. Ülke bu yıllarda Amerikan yardımları sayesinde ekonomik olarak gelişmiştir. 1959 yılının sonuna kadar Amerika Birleşik Devletleri Libya'ya 100.000.000 dolar yardımda bulunmuştu ${ }^{35}$.

Kral İdris parlamentoüzerindeki ağırlığını artırdıktan sonrakendisine bağlı kabilelerden oluşmuş olan orduyu tamamen kontrolü altına aldı. Aynı zamanda çevresindeki kabileleri onlara petrolden daha fazla pay vererek daha fazla himaye etti. Fakat demokratikleşme yönünde izlediği karmaşı ve tutucu politikalar ve belli kabileleri desteklemesi yüzünden gözden düştü. Aynı zamanda bu dönemde gelişen Arap milliyetçiliğinin etkilerini iyi

33 Ruth First, Libya The Elusive Revolution (New Zealand Penguin African Library, 1974), 75-77.

34 Ahmet Kavas, "İdrîs I”, İstanbul: Türkiye Diyanet Vakfi İslam Ansiklopedisi, C XXI., (2000), 482.

35 El-Kihya, 73-76. 
okuyamadığı için Cemal Abdul Nasır'a hayranlık duyan birçok asker ve orta sınıf mensupları tarafından yoğunca eleştirildi. 1969 yılında kaplıca tedavisi için Bursa şehrinde tatilini geçirirken 1 Eylül 1969'da orduda etkin ve sevilen bir subay olan Saadettin Ebuşvereb ihtilal yaparak iktidarı devraldı. Ondan da kontrolü İngiltere Harp Okulu mezunu Yüzbaşı Muammer Kaddafi devraldı. Böylece ülkede uzun süren bir Kaddafi dönemi başlamış oldu ${ }^{36}$.

Kaddafi yönetimi ele geçirdiğinde sadece 27 yaşındaydı. Kendi isteği yönünde yeni bir Libya toplumu yaratmak için harekete geçti. Bürokrasi yeniden oluşturdu. Çoğu Libya'nın üst düzey kabilelerine mensup olan önemli şahsiyetleri tasfiye etti. Aynı zamanda kabile liderleri başta olmak üzere kendisine muhalif gördüğü kimseleri zayıflatmaya başladı. Ülkedeki kabilelerin idari sınırlarını yeniden çizdi. Böylece kendisini destekleyen kabilelerin sınırlarını genişletip, kendisine muhalif durumda olanların topraklarını daralttı. Kaddafi iktidarını sağlamlaştırırken eski rejimde güç kazanmış bazı dini liderler kendisine muhalefet göstermeye başladı. Fakat Kaddafi bunlarla kavga etmenin kendisinin aleyhine olacağını anlayınca daha çok dini nitelikli yasalar çıkarmaya başladı. Alkol kullanımını yasakladı, dini motifleri konuşmalarında çok sık kullandı. Böylece Libya'da etkili olan dini liderlerin etkisini zayıflatmayı umdu. Kaddafi gerici yaftasılla öncelikle Senusi cemaatlerini dağıtmaya başladı. Birçok dini lider tutuklanıp işkence gördüler.

Henüz çok gençken ve siyasi tecrübesi yokken akıl hocası Nasır'ın Mısır'da oluşturduğu idari sistemin benzerini Libya'da oluşturmak istedi. Bu yüzden ülke Kaddafi döneminde Mısır'a iyice yakınlaştı. Devrimin ilk yıllarında Libya'nın Mısırlılaştırılma çabaları 1970'lerde iki ülke arasında birlik kurulmasıyla sonuçlandı. Ayrıca Mısır, Libya ordusu üzerinde son derece etkiliydi. Bu dönemde Libya ordusu silahlarını bile Misır ordusundan alıyordu. Libya'nın devrimden sonraki resmi sloganı "özgürlük, sosyalizm ve birlik" olmuştu. Kaddafi Haziran 1970'de ülkedeki ABD ve İngiliz üstlerini kapattı. Sovyetler Birliği ile askeri dayanışma içine girdi ${ }^{37}$.

Kaddafi üçüncü evrensel teori adını verdiği ve kendi ifadesiyle İslam ile sosyalizmi sentezleyen bir ideolojiyi benimsemişti. 15 Nisan 1973 tarihinde Zawara Beyanı olarak bilinen açılaması ile ideolojisini daha da netleştirmiş ve halk devrimi olarak nitelendirdiği dikta rejiminin önündeki yasal ve yönetsel engelleri kaldırmak maksadıyla ülke bürokrasisini ve aydınları kontrol altına almıştır. Kaddafi daha sonra Kuran, İslam, toplum ve devlet ile olan düşüncelerini 1975 yılında Yeşil Kitap adını verdiği kitabında topladı ${ }^{38}$.

1969 yllındaki yeni anayasaya göre; Devrim Komuta Konseyi ülkede en üstün siyasi otorite olarak görülmeye başladı. Aynı yıl Arap Sosyalist Birliği’nin kurulmasına

36 Türkmen, 165.

37 Mirella, Bianco, Gaddafi Voice From The Desert (Paris, Edition Stock, 1975), 70.

38 Yeşil Kitap 1975 ile 1981 arasında yayınlanan üç kısımdan oluşmaktadır. 1975’te yayınlanan ilk kısmı "Demokrasi Sorununa Çözüm: Halkın İktidarı", 1977'de yayınlanan ikinci kısmı "İktisadi Sorunlara Çözüm: Sosyalizm" ve 1981'de yayınlanan son k1smı ise "Üçüncü Evrensel Teorinin Sosyal Temeli" isimlerini taşımaktadır. Özellikle ilk kitaba göre doğrudan demokrasiye vurgu yapılmış, normal demokrasinin ise sadece çoğunluğun diktatörlüğünü kurduğunu ve azınlığın ise kendisinin seçmediği kişilerce yönetilmeye razı olduğunu vurgulanmıştır. Böylece doğrudan demokrasi ile halk konseylerinin meşruluğu artırılmaya çalışılmıştır. Vandewalle, Libya Since İndependence Oil And State Building, 75-78. 
çalışılmış böylece siyasal muhalefetin faaliyetleri kısıtlanmaya başlanmıştır. Ayrıca bu dönemde devletin kurumlarında kökten değişiklikler yapılmaya başlanmış, Kaddafi'ye yakın kimseler devlet kurumlarının başına getirilmeye başlanmıştır. Devlet kontrolünün güçlü olması bireysel sermayenin etkisini azaltmış ve devletçi bir ekonomi anlayışı ülkeye hâkim olmuştur ${ }^{39}$.

Zawara Beyanı ile rejim aleyhtarı kişilerin tasfiye edilme süreci hızlanmıştır. $\mathrm{Bu}$ beyana göre yürürlükteki tüm yasalar ve bürokrasi ortadan kaldırılmış ve kültür devrimi ilan edilmiştir. Bu aşamadan sonra kendisine muhalif olabilecek kişilere karşı tutuklama dalgası başlatılmıştır. Özellikle devrik kral Kaddafi, ülke içerisinde yaptığı bu baskıcı politikaların sonucunda yönetim krizine sebep olmuş, 1975 yılında Kaddafi'yi devirmek için başarısız bir darbe girişimi tertiplenmiştir. Bu darbe girişiminin sonucunda ise daha şiddetli bir bask1 politikası muhaliflere karşı uygulanmıştır ${ }^{40}$.

Ocak 1976'da Arap Sosyalist Birliği kurma yetkisi Halk Kongreleri dışında Genel Halk Kongresine verilmiştir. Bu kurum bir sekreter ve 20 bakandan oluşan bir konsey oluşmaktadır. Ve ülkeyi Kaddafi rejiminin sonuna kadar yönetmiştir. Bu kurum adaletten, eğitime, kamu düzenine ve finansa kadar birçok alanda tam yetkili mercii konumuna yükselmiştir. 1979' da ise Devrim Konseyi kurulmuş böylece yönetim çift başıı bir yapıya bürünmüştür. Bir tarafta halk konseyleri yönetim yetkisini suni bir şekilde yürütürken, Kaddafi kendisine yakın kimselerden oluşan askeri ve istihbarat işlerini yöneten elit bir yönetim kadrosu oluşturmuştur ${ }^{41}$.

Kaddafi, halk konseyleri tarafından yönetilen belediyelerden oluşan üçüncü dünyac1 Cemahiriyye sistemini ise 1977 yılında kurdu. 2 Mart 1977' de yönetimden ayrıldığını ve artık egemenliğin halk otoritesinde olduğunu belirtti. Bu dönemde kurmuş olduğu Halk konseyleri, anarşizmin katılımcılı̆̆ını andırıyordu. Konseye seçimle gelinmiyor, doğrudan katılımdan bahsediliyordu. Ama gerçek anlamda bir yönetim gücü bulunmuyordu. Genelde belirleyici olan devrim konseyinin istekleriydi. Ne meclis ne mebus ne de düzenli bir bakanlar kurulu vardı. Kaddafi'ye göre demokrasi kötüydü, bunun içinde Cemahiriyye sistemi doğrudan demokrasiyi temsil ediyordu. Fakat petrol kaynaklarının ve gelirlerinin tamamını kullanma yetkisine sahip olan Kaddafi'yi hiçbir kontrol mekanizması denetleyemiyordu. Ülkedeki halk komitelerinin liderleri, genel olarak Kaddafi'yle aynı kabileden gelen kişiler arasından seçiliyordu. Ayrıca devrim komitesi üyeleri, ülkenin her bölgesinde devrimi ve Kaddafi'nin fikirlerini yaymak zorundaydılar. Komite üyeleri güç kazanmaya başladığında komiteden tavsiye ediliyorlardı. Kaddafi kendisine bağlı olan üyelere ise çok iyi davranıyordu. Bu üyeler genelde Kaddafi tarafından destekleniyor ve yurt dışındaki halk bürolarında, bankalarda ve resmî kurumlarda görevlendiriliyorlardı.

Devrim Komitesinin kurmuş olduğu devrim mahkemeleri sonucunda birçok haksız

39 Dirk Vandewalle, A History of Modern Libya (Cambridge: Cambridge University Press Second Edition, 2012), 60-61.

40 Alı Abdullatıf Ahmida, Forgotten Voices: Power and Agency in Colonıal and Postcolonial Libya (New York: Routledge, 2005), 78-80.

41 "Seta Raporu Batı ve Kaddafi Makasında Libya” (Ankara: Seta Yayınları, No:3, Mayıs 2011), 9-10. 
tutuklama ve infaz gerçekleştirilmiştir. Böylece rejimin güvenirliğini tehdit edecek girişimler önlenmek istenmiştir. Fakat ilerleyen dönemde devrim mahkemelerinin yapmış olduğu keyfi tutuklamalar halkın tepkisini çekince bu devrim konseylerinin yetkileri azaltılmış bunun yerine Kaddafi'ye daha bağımlı devrim muhafizları kurulmuştur. Ayrıca Kaddafi bu dönemde Cemahiriyye' de kendisine bağlı kabileleri destekleyerek kabileleri birbirlerine karşı kışkırtmış böylece kuralların ve kurumların desteklediği bir devlet yapısı yerine zayıf bir devlet yapılanması oluşturmuş̧ur. ${ }^{42}$

Kaddafi'nin Sirte'deki kendi kabilesi olan Kaddafa kabilesi ile Beni Valid eyaletindeki Warfatla kabilesi ile Magarha kabilesi ülkenin en etkin kabileleri olmuşlar, diğer kabilelere karşı ortak hareket etmişlerdir. Ve diğer kabilelerin güçlenmesini önlemeye çalışmışlardır. Aynı zamanda bu kabilelere mensup kişiler devlet kademelerine kolayca yerleştirilmiş ve yönetimde etkin şekilde yer almışlardır. ${ }^{43}$ Bunun yanında ülkedeki Berberilerin kendi dillerinde ve kültürlerinde eğitim hakkı verilmemiş kültürleri üzerine baskı kurulmuştur. Ayrıca devrim subayları Sufizmi devrim dışı ilan etmişler bu durumda Selefiliğin bölgede yayılması üzerine Kaddafi bölgede kendisine düşman olarak gördüğü Suudi Arabistan'ın etkinlik kazanmasını önlemek için tekrar Sufizm' in etkinlik kazanmasına çalışmışlardır ${ }^{44}$.

Kaddafi 1979 y1lına geldiğinde ülke içerisindeki gücünü iyice pekiştirmişti. Ordu içerisinde Hizbu't-Tahrir'le ilişkisi olduğu saptanan 10'dan fazla subay idam edildi. Darbe yapacağından çekindiği için orduyu dağıttı ve yerine Afrika ülkelerinden getirilen aylık 2.500 dolar verilen 50 bin kişilik bir ordu kurdu. 1980-87 yılları arasında Libya dışına kaçan 25 Libyalı muhalif önder suikasta uğradı. 1996 yılında Ebuslim hapishanesinde 1270 kişi katledildi. Aynı zamanda Kaddafi'nin iktidarda bulunduğu 42 yıl içerisinde 45 bin kişi kayboldu. Ülkedeki İslamcılar arasında ise Kaddafi rejimine en muhalif kesim İhwan-ı Müslimin idi. Kaddafi döneminde birçok üyesi tutuklanmış ve idam edilmişti. Aynı zamanda liderliğini Abdülkerim Belhac'ın yaptığı Değişim İçin Libya Hareketi Kaddafi ile sıkı bir mücadeleye girmiş özellikle 1990'lı yıllarda sempatizanları öldürülmüş veya sürgüne gönderilmişti. Hizbu't Tahrir'in de Kaddafi döneminde birçok üyesi hapsedildi ve idam edildi. Bunun yanında Davet ve Tebliğ grubunun liderleri yurtdışında suikasta

42 Dirk Vandewalle, "The Libyan Jamahiriyya since 1969", In D. Vandewalle, (Ed.), Qadhafi's Libya, 1969-1994 (New York: St. Martin's Press, 1994), 200-210; Mehmet Ercan Baltalı, Libya'da Kaddafi Dönemi: Yönetim Tarzı ve Yarattığı Sorunlar (Malatya İnönü Üniversitesi Sosyal Bilimler Enstitüsü Yayımlanmamış Yüksek Lisans Tezi, 2019), 22.

43 Mohamed Eljarh, "Libya's Fight for the Rule of Law," Foreign Policy, April 4, 2013. As of January 22, 2014: http://transitions.foreignpolicy.com/posts/2013/04/04/ libya_s_fight_for_the_rule_of_law. (Ulaşım Tarihi: 15.06.2019).

44 Christopher S. Chivvis, Jeffrey Martini, "Libya After Qaddafi Lessons and Implications for the Future", Rand Corporation, California, 2014. https://www.rand.org/pubs/research_reports/RR577.html. (Ulaşım tarihi: 10.07.2019). 
uğramışlardi ${ }^{45}$.

İslami muhalefetin yanında, son 15 yıldır yaşanan ekonomik problemler ülkede huzursuzluğun artmasına sebep oluyordu. Özellikle bazı kesimler ülke ekonomisini bitmek tükenmek bilmeyen bir krize sokan politikaları sorguluyorlardı. Özellikle dış politikada Kaddafi'nin sergilemiş olduğu düşmanca ve bilinçsizce tutum ülkeyi adeta kapalı bir kutu haline sokmuştu. Ülke uluslararası arenadaki terörist faaliyetleri sonucunda uluslararası ambargolara maruz kalmıştı. Ayrıca Libya'nın petrol gelirlerinin Kaddafi tarafından hesapsızca ve kendi yandaşlarına yarayacak şekilde kullanılması ekonomik problemleri artırmış, refahın yeterince yayılamaması sonucunda da işsizlik, yoksulluk gibi sosyal problemler artmışt1 ${ }^{46}$.

Sonuç olarak; son 20 yıldır Libya toplumunda resmi ve gayri resmî kurumların yapılarında birçok değişiklik oldu. Ülkede değişmeyen tek şey, ülkenin tek güç kaynağ1 General Kaddafi ve onun yakın çevresiydi. Ülkede Kaddafi'nin ürettiği politikalara karşı hiçbir muhalefetin oluşmasına izin verilmedi. Oluşmaya çalışılan muhalefet ise hain olarak yaftalanıyor ve yok ediliyordu. Muhalefetin olmayışı, insan haklarından ve özgürlüklerden yoksun bir yönetim, ekonomik buhranlar ve diğer etkenler artık bir değişimin olacağının haberini veriyordu. Beklenen bu değişim ise Arap isyanlarıyla vücut buldu.

\section{Sonuç}

Kuzey Afrika’nın iki önemli ülkesi Fas ve Libya geçmişten gelen geleneksel bağlarla kabile ve klanların egemen olduğu bir sistemle yönetilmişlerdir. Kuzey Afrika bölgesinin birçok devletin egemenliğine girmesi ve ilerleyen dönemde bölgeye Arap akınlarının olması bölgenin demografik yapısında birçok değişiklik meydana getirmiştir. Bölgenin Memluk ve Osmanlı Devleti'ne geçmesi sonrasında ise bölgede Dayı ve Beylerin egemenliğinde görece özerk devlet yönetimleri kurulmuştur. Çalışmamızı ilgilendiren 19. yüzyılda ise bölgeye Avrupalı güçlerin girmesi ile Fas'ın bazı bölümleri İspanya ve Fransa tarafından kantonlara bölünmüştür. Daha sonra Fas’ta Fransa'nın manda yönetiminde bir monarşi kurulduğu anlaşılmaktadır. Libya ise İtalyan işgali sonrasında direniş hareketleri 1934 senesine kadar sürmüş, ilerleyen dönemde Senusi hanedanının kabileler üzerinde etkin gücü ile bir siyasi birlik kurabilmiştir. Manda yönetimleri sırasında valilikler tarafından yönetilen bu iki ülkede, dönemin konjonktürüyle alakalı olarak bağımsızlıktan sonra monarşiye dayalı, ulus milliyetçiliğinin egemen olduğu ve dini aidiyet duygusuyla zenginleştirilmiş birer teokratik hanedanlık kurulmak istenmiştir. İki ülke her ne kadar birbirinden farklı görünseler de monarşilerin hazreti Muhammed'in soyuyla kurmak istediği bağ yönetimin meşruiyet kazanmasını sağlamış ve ülkeyi oluşturan farklı grupların bir araya gelmesinde önemli bir çimento görevi görmüştür.

İki ülkenin manda yönetiminden sonra kurduğu siyasi yapılar da her ne kadar bağımsız görünse de Avrupalı devletlerin isteklerine göre şekillenmiştir. Özellikle İngilizlerin Libya kralına verdiği destekler, Fransa'nın Fas’ta istediği kralı tahta geçirmesi bu ülkelerde üstü kapalı imtiyazlarını devam ettirme çabasıyla ilgilidir. Fas özelinde manda yönetiminden sonra 
Kral Muhammed'in izin verdiği ölçüde siyasi ve demokratik düzenin oluşmaya başlaması, yönetimde kendi adamlarının egemen olduğu küçük bir oligarşik yapıya dönüşmüştür. Demokratik partilerin ve anayasal sitemin sözde kaldığı bu yapıda ilerleyen dönemde Kral Muhammedîn tüm gücü elinde topladığ1 ve muhalif hareketleri bask1 ile sindirdiği bir yönetim şekli oluşmuştur. Yukarıda anlattığımız gibi kendi iktidarını sağlamlaştırmak için zamanla bütün yetkileri oğlunda toplayarak siyaset sahasında tek gücü elinde toplamış ve rejimine muhalif gördüğü siyasi yapıları tasfiye etme yolunu seçmiştir. Fakat daha sonra bu politikaların sürdürülemeyeceğini anlamış ve demokratikleşme çabalarına destek vererek yeni bir politika sergilemeye başlamıştır. Kendisinden sonra reformları devam ettiren oğlu VI. Muhammed ise sosyal politikalara önem vererek var olan huzursuzlukları engellemeye çalışmıştır.

Libya'da ise Manda yönetiminden sonra Senusi Hanedanlığının elinde bulunan yönetim çeşitli kabile ortaklıklarıyla yürütülmeye çalışılmış, fakat tam bir bütünleştirici yönetim sistemi sağlanamadığından bir rejim değişikliği yaşanmıştır. O dönemde Nasır'ın tam bağımsızlık hareketinden etkilenen subaylar tarafından Arap milliyetçiliği, ulusal ögelerin vurgulandığı, sosyalizm ağırlıklı kurulmaya çalışılan yeni düzen, Kaddafi'nin ütopik siyasi teoremleri sonucunda erozyona uğramıştır. Bu dönemde yeşil kitabı yayımlayan, doğrudan demokrasiyi savunan ve Cemahiriyye adında yerel yönetimlerin etkili olduğu bir sosyalizme dayalı bir yapı oluşturan Kaddafi, zamanla bu ideolojilerin dışına çıkarak ülkede kendisinin kabilesine dayalı oligarşik bir sistem kurmuştur. Orduya ve kamu makamlarına kendisinin veya ona yakın kabilelerin üyelerine atayan Kaddafi, ülkenin zengin petrol gelirlerini dilediği gibi kullanmıştır. Fakat her ne kadar petrol gelirleri sayesinde birçok sosyal yardım yapmış olsa da zamanla ülkesini dünya da yalnızlaştıran politikalar izlemesi yüzünden ülkesi tam olarak kalkınamamış, gelirler tabana yayılamamıştır. Ayrıca ülkedeki muhalif kesimi oluşturan berberiler, İslamcılar ve diğer grupların etkili bir siyasi faaliyet yürütmelerine izin verilmemiştir. Nitekim Arap Baharı sürecinde de düşman olduğu bu muhalif gruplar tarafından iktidardan düşürülmüştür. Bugüne baktığımızda iç çatışmaların yaşandığı Libya demokratik bir kültürün olmadığı ve kabile yapılarının hala etkin olduğu bir ülke olarak göze çarpmaktadır. Arap Baharı sürecinde Fas'ta ise her ne kadar geçmişte baskıc1 ve totaliter bir görünüm sergilese de ülkenin son kralı 6. Muhammed'in bazı reformlar yapması ve demokratik gelişimin önündeki engelleri kaldırmak için yapmış olduğu çabalar bu ülkede bir devrime yol açmamıştır.

\section{Kaynakça}

Abdallah, Larou1. The History of the Maghrıb. New Jersey: Princeton, 1977.

Abun-Nasr, Jamil. A History Of The Maghrib. Cambridge: Cambridge University Press, 1975.

Ahmida, Alı Abdullatıf. Forgotten Voices: Power and Agency in Colonial and Postcolonial Libya. Newyork: Routledge, 2005.

Bianco, Mirella. Gaddafi Voice From The Desert. Paris: Edition Stock, 1975.

Baltalı, Mehmet Ercan. “Libya'da Kaddafi Dönemi: Yönetim Tarzı ve Yarattığı 
Sorunlar”. Malatya: İnönü Üniversitesi Sosyal Bilimler Enstitüsü Yayımlanmamış Yüksek Lisans Tezi, 2019.

Cambon, Henri. Histoire Du Maroc. Paris: Librairie Hachette, 1952.

Cohen, Mark I-Hahn, Lorna. Morocco Old Land New Nation. London: Pall Mall Press, 1966.

El-Kihya, Mansur Ömer. Libya’nın Kaddafisi. İstanbul: Kaknüs Yayınları, 2011.

First, Ruth. Libya The Elusive Revolution. New Zealand: Penguin African Library, 1974.

Howe, Marvine. Morocco The İslamic Awakening and Other Challenges. London: Oxford University Press, 2005.

Karasapan, Celal Tevfik. Libya, Trablusgarp, Bingazi ve Fizan. Ankara: Resimli Posta Matbaası Ltd. Şirketi, 1960.

Karcı, Erol. Osmanlı Kaynaklarına Göre Fransa'nın Tunus'u İşgali. Ankara: Gazi Üniversitesi SBE Tarih Ana Bilim Dalı Yayımlanmamış Yüksek Lisans Tezi, 2007.

Kavas, Ahmet. "İdrîs I". İstanbul: Türkiye Diyanet Vakfi İslam Ansiklopedisi, C. XXI., (2000): 481-483.

Khadduri, Majid. Modern Libya A Study in Political Development. Baltımore: The Johns Hopkins Press, 1963.

Lagendijk, Joost-Wiersma, Jan Marinus, Avrupa'nın Müslüman Komşuları. İstanbul: İletişim Yayınları,

Morsy, Magali. North Africa 1800-1900 A Survey From The Nile Valley To The Atlantic. London: Addison-Wesley Longman Ltd, 1984.

Şıvgın, Hale. Trablusgarp Savaşı ve 1911-12 Türk-İtalyan ilişkileri. Ankara: Atatürk Araştırma Merkezi Yayınları, 2006.

Tozy, Muhammed. “Champ Et Contre Champ Politico-religieux au Maroc”. Marseille: Thcse pour le Doctorat d'etat en Science Politique, Universite de Droit, d'Economie et de Sciences d'Aix-marseille, 1984.

Trout, Frank E. Morocco's Saharan frontiers. Geneva: Librairie Droz, Vol. 1., 1969.

Vandewalle, Dirk. "The Libyan Jamahiriyya since 1969". In D. Vandewalle, (Ed.), Qadhafi’s Libya, 1969-1994, New York: St. Martin's Press, 1994.

Vandewalle, Dirk. Libya Since İndependence Oil And State Building. London: Cornell University Press, 1998.

Vandewalle, Dirk. A History of Modern Libya. Cambridge: Cambridge University Press, Second Edition, 2012.

William, Zartman-William, Mark Habeeb. Policy and Society in Contemporary North Africa. San Francisco: Westview Press, 1993.

WRIGHT, Jack. Libya: A Modern History. London: Croom Helm, 1981. 


\section{İnternet Kaynakları}

Eljarh, Mohamed, "Libya's Fight for the Rule of Law," Foreign Policy, April 4, 2013. As of January 22, 2014: http://transitions.foreignpolicy.com/posts/2013/04/04/ libya_s_ fight_for_the_rule_of_law.

Christopher S. Chivvis, Jeffrey Martini, Libya After Qaddafi Lessons and Implications for the Future, Rand Corporation, California, 2014. https://www.rand.org/pubs/research reports/RR577.html. (Ulaşım tarihi: 10.07.2019).

"Seta Raporu Batı ve Kaddafi Makasında Libya", Seta Yayınları, No:3, Ankara, Mayis 2011. 